\title{
The Relationship of Vitamin D Deficiency in Type 2 Diabetes Patients: Dhaka, Bangladesh

\author{
Dr. Amal Krishna Paul ${ }^{1 *}$, Dr. Arifa Sultana ${ }^{2}$, Dr. Ismat Ara Begum ${ }^{3}$
}

\author{
${ }^{1}$ Consultant (Medicine), SMC Niltara Clinic, Dhaka, Bangladesh \\ ${ }^{2}$ Medical Officer, Life Diagnostic Centre, Nayapaltan, Dhaka, Bangladesh \\ ${ }^{3}$ Advanced Health Care for Women, Dhaka, Bangladesh
}

DOI: $10.36347 /$ sasjm.2021.v07i03.004

| Received: 28.02.2021 | Accepted: 16.03.2021 | Published: 23.03.2021

*Corresponding author: Dr. Amal Krishna Paul

Abstract

Original Research Article

Introduction: Diabetes mellitus (DM) is a result of heterogeneous metabolic disorders, causes hyperglycemia due to deficiency in secretion and/or insulin action. The present retrospective cross-sectional study was done among 78 T2DM patients. Serum 25-hydroxyvitamin D [25(OH)D] levels reflect body stores of vitamin D which was measured in all and classified as normal $(\geq 30 \mathrm{ng} / \mathrm{mL})$, insufficient $(>20$ to $29.9 \mathrm{ng} / \mathrm{mL})$, and deficient $(\leq 20 \mathrm{ng} / \mathrm{mL})$. The mean serum 25(OH) D level was $27.91 \pm 2.58 \mathrm{ng} / \mathrm{mL}$ (mean $\pm \mathrm{SD}$ ). Aim of the Study: Aim of the study was to find out the vitamin D status in type 2 diabetes mellitus patients. Methods: This retrospective cross-sectional study was conducted in SMC Niltara Clinic, Dhaka, Bangladesh during the period from January 2020 to December 2020. All the results were statistically analysed by were taken by SPSS-20 version and MS-Excel-16. Result: In total 78 patients divide into two groups. In Vitamin-D status was 24(41.38\%) found normal in male and $8(40.00 \%)$ in female; insufficient found $22(37.93 \%)$ in male and $11(55.00 \%)$ in female; deficient found $12(20.69 \%)$ in male and $1(5.00 \%)$ in female. There was no statistical difference of $25(\mathrm{OH}) \mathrm{D}$ level between males and females $(26.79 \pm 2.1 \mathrm{vs}$. $31.09 \pm 8.2 \mathrm{ng} / \mathrm{mL}$, mean \pm SEM; $p=0.470)$; among smokers, non-smokers and ex-smokers $(26.86 \pm 4.31,27.10 \pm 2.49$ and $42.62 \pm 1.71 \mathrm{ng} / \mathrm{mL}$ respectively, mean \pm SEM; $\mathrm{p}=0.363)$; among normal weight, overweight and obese $(30.61 \pm 6.16,35.61 \pm 9.52$ and $24.27 \pm 1.71 \mathrm{ng} / \mathrm{mL}$ respectively, mean $\pm \mathrm{SEM} ; \mathrm{p}=0.191)$; and among normotensive, borderline hypertensive and hypertensive $(25.29 \pm 2.46,32.57 \pm 5.32$ and $20.84 \pm 3.66 \mathrm{ng} / \mathrm{mL}$ respectively, mean $\pm \mathrm{SEM}$; $\mathrm{p}=0.277)$ patients. $25(\mathrm{OH}) \mathrm{D}$ level showed significant negative correlation with body mass index $(r=-0.391, p=0.017)$ and positive correlation $(\mathrm{r}=0.334, \mathrm{p}=0.044)$ with fasting plasma glucose in male subjects. Conclusion: A large portion of Type-2 diabetes mellitus (DM) subjects in Bangladesh has subnormal vitamin D as revealed by our study. Vitamin D level had a significant negative correlation with BMI only male subjects and showed no correlation with sex and other veriables. However, wider scale studies are needed to properly understand the vitamin D status in Type- 2 diabetes mellitus (DM) in our country.

Keywords: Diabetic mellitus, Vitamin D defficiency, Insulin.

Copyright (C) 2021 The Author(s): This is an open-access article distributed under the terms of the Creative Commons Attribution 4.0 International License (CC BY-NC 4.0) which permits unrestricted use, distribution, and reproduction in any medium for non-commercial use provided the original author and source are credited.

\section{INTRODUCTION}

A common endocrine disease named diabetes mellitus (DM) as a result of heterogeneous metabolic disorders, causes hyperglycemia due to deficiency in secretion and/or insulin action. About 415 million people affecting worldwide by this [1]. In 2015, Bangladesh ranked 10 in the world with a total of 7 million diabetic people \& it is estimated that 13.6 million people in around 2040 will have diabetes, will make 9th in the ranking at that time1. It includes two main types: type 1- destruction of insulin-producing pancreatic $\beta$-cells; type- 2 , the peripheral resistance of insulin hormone [2]. The prevalence of diabetes has been increasing in epidemic proportions, with long-term complications [3]. DM have many complication, one of these complication is diabetic foot ulcer (DFU) has described as infection, ulceration and/or destruction of deep tissues associated with neurological abnormalities and various degrees of peripheral vascular disease [3, 4]. It is commonly caused by repetitive stress in patients with peripheral neuropathy [5], or initial injury (trauma) that is not detected by the patient [6], together with a peripheral vascular disease, plus contributes to the development of foot ulcers [7]. Vitamin D is steroid hormone fat-soluble [8, 9]. It discovered in 1922 by McCollum and mostly derived from sun exposure like 
synthesized in the skin, and a small amount from the diet including fish milk, yogurt, orange juice, and cereals [10]. Its synthetizing mainly made on the skin with the effect of ultraviolet light [9] and activated by two hydroxylation reactions in the liver and kidneys [11]. In a word vitamin D status is an excellent marker of 'good health' (positive associations with young age, normal body weight, and a healthy lifestyle). It plays a vital role in bone metabolism and the regulation of intestinal absorption of minerals (calcium \& phosphorus). Various studies suggest that vitamin D deficiency may play a major role in the causation of type 2 diabetes mellitus (T2DM) [12-14] Vitamin D may also play role in glycemic control in DM $[15,16]$. Serum 25-hydroxyvitamin D [25(OH)D] levels reflect body stores of vitamin D [17] which was measured in all and classified as normal $(\geq 30 \mathrm{ng} / \mathrm{mL})$, insufficient $(>20$ to $29.9 \mathrm{ng} / \mathrm{mL})$, and deficient $(\leq 20 \mathrm{ng} / \mathrm{mL})$. The mean serum $25(\mathrm{OH})$ D level was $27.91 \pm 2.58 \mathrm{ng} / \mathrm{mL}$ (mean \pm SD).Worldwide vitamin $\mathrm{D}$ deficiency is a common problem in the general population [18]. Although vitamin D deficiency is unexpected in tropical areas like the Indian subcontinent, several crosssectional studies found a very high prevalence of vitamin D deficiency even among healthy individuals of various subsets of this population [19-21]. Recent studies have reported a very high prevalence of subnormal vitamin D in T2DM patients in this subcontinent, though some of those studies reported that the prevalence was not significantly higher when compared to normal individuals [22-24]. There is a lack of data on the prevalence of vitamin D deficiency among Bangladeshi T2DM patients. Hence, this study was undertaken to investigate the vitamin $\mathrm{D}$ status in T2DM patients in a tertiary care hospital.

\section{OBJECTIVES}

- To identify the relationship of vitamin D deficiency in the diabetic patients.

- Investigate the vitamin-D status in T2DM.

\section{METHODOLOGY \& MATERIALS}

This was a retrospective cross-sectional study and was conducted in SMC Niltara Clinic, Dhaka, Bangladesh during the period from January 2020 to December 2020. Purposive sampling study technique was used for this study. Patients taken diagnosed after the age of 20 years with central obesity, acanthosis nigricans, and other features of insulin resistance and having no ketosis were categorized as T2DM. Informed written consent was included for study. Patients having a history of poor sunlight exposure; liver, kidney, or thyroid dysfunction; malignancy, recent severe acute illness; strict vegans, and those taking vitamin D supplements were excluded. $5 \mathrm{ml}$ venous blood was collected from each of the participants, serum separated by centrifugation and preserved until assay. Serum 25(OH)D was estimated by chemiluminescent immunoassay procedure. $25(\mathrm{OH}) \mathrm{D}$ levels were considered as normal $(\geq 30 \mathrm{ng} / \mathrm{mL})$, insufficient $(>20$ to $\leq 29.9 \mathrm{ng} / \mathrm{mL})$, and deficient $(\leq 20 \mathrm{ng} / \mathrm{mL})$ as per Clinical Practice Guidelines 2011 of The Endocrine Society [25]. Obesity status was determined by body mass index (BMI) categories applicable for the Asian Indians [26]. All the relevant data were analyzed by using SPSS version 20 software (SPSS Inc; Chicago, IL, USA). The categorical variables were represented as percentages and measurable variables as mean \pm SD. Independent sample t-test, Chi-square test, or oneway ANOVA was performed as applicable for comparing the variables between different groups. Pearson's correlation test was done to find out the association among different variables, and a regression model was applied to identify the confounding variables. P-value $\leq 0.05$ was considered to be statistically significant.

\section{RESULT}

Out of 78 patients we found $58(74.36 \%)$ male and $20(25.64 \%)$ female (Figure-1). Of the total sample size, the majority belonged to the obese category $48(61.54 \%)$, then $19(24.36 \%)$ were overweight and $11(14.10 \%)$ were of normal body weight (Figure-2). Looking at the clinical and laboratory characteristics of the patients, $56(71.82 \%$ ) had a family history of type 2 DM and 22(28.21\%) patients was absent. Of the 78 patients, $40(51.28 \%)$ were non-smoker, $5(6.41 \%)$ were ex-smoker, and the remaining $34(43.59 \%)$ were smokers. Categorizing them based on their blood pressure, $8(10 \%)$ were hypertensive, $31(39.74 \%)$ were borderline hypertensive, and the remaining $38(6.41 \%)$ were of normotensive category (Table-1). The correlation between $25(\mathrm{OH}) \mathrm{D}$ levels and other factors, divided between the male and female groups showed that significant inverse correlation with BMI only in male groups $(\mathrm{r}=-0.391, \mathrm{p}=0.017)$, also showed that $25(\mathrm{OH})(\mathrm{r}=0.334, \mathrm{p}=0.044)$ FPG in males; but in females it had negative correlation $(r=-0.537, p=0.058)$ with the same. Other factors (systolic blood pressure, and diastolic blood pressure) were not found to have any significant correlations with $25(\mathrm{OH}) \mathrm{D}$ levels There was no statistical difference of $25(\mathrm{OH}) \mathrm{D}$ level between males and females $(26.79 \pm 2.1$ vs. $31.09 \pm 8.2 \mathrm{ng} / \mathrm{mL}$, mean \pm SEM; $\mathrm{p}=0.470)$; among smokers, non-smokers and ex-smokers $(26.86 \pm 4.31,27.10 \pm 2.49$ and $42.62 \pm 1.71 \mathrm{ng} / \mathrm{mL}$ respectively, mean $\pm \mathrm{SEM} ; \mathrm{p}=0.363$ ); among normal weight, overweight and obese $(30.61 \pm 6.16, \quad 35.61 \pm 9.52$ and $24.27 \pm 1.71 \mathrm{ng} / \mathrm{mL}$ respectively, mean \pm SEM; $\mathrm{p}=0.191)$; and among normotensive, borderline hypertensive and hypertensive $(25.29 \pm 2.46, \quad 32.57 \pm 5.32$ and $20.84 \pm 3.66 \mathrm{ng} / \mathrm{mL}$ respectively, mean \pm SEM; $p=0.277)$ patients. $25(\mathrm{OH}) \mathrm{D}$ level showed significant negative correlation with body mass index $(\mathrm{r}=-0.391, \mathrm{p}=0.017)$ and positive correlation $(\mathrm{r}=0.334, \mathrm{p}=0.044)$ with fasting plasma glucose in male subjects (Table-2). None among the variables of age, sex, smoking status, BMI, systolic BP, diastolic BP, family history of DM, and smoking status were found to influence $25(\mathrm{OH}) \mathrm{D}$ level independently 
\& $\mathrm{p}$ value is not significant for all (Table-3). In Vitamin-D status was 24(41.38\%) found normal in male and $8(40.00 \%)$ in female; insufficient found
$22(37.93 \%)$ in male and $11(55.00 \%)$ in female; deficient found $12(20.69 \%)$ in male and $1(5.00 \%)$ in female (Table-4).

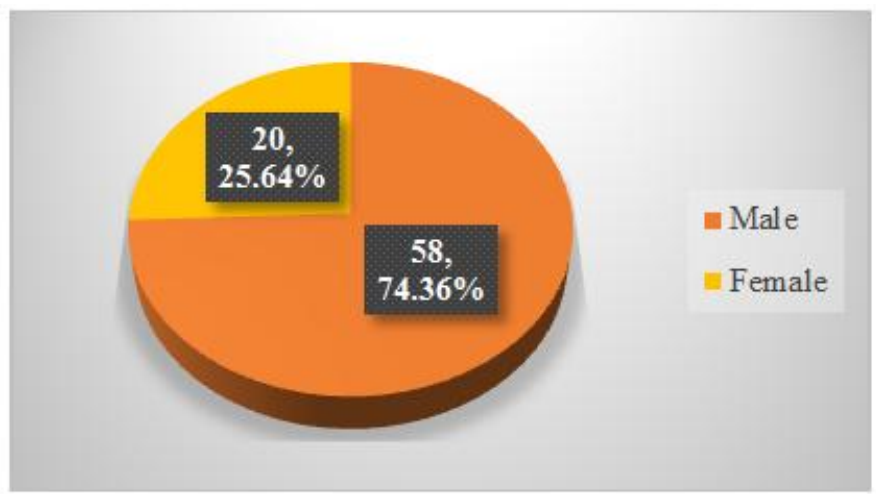

Fig-1: Distribute the study patients according to gender $(\mathrm{N}=78)$

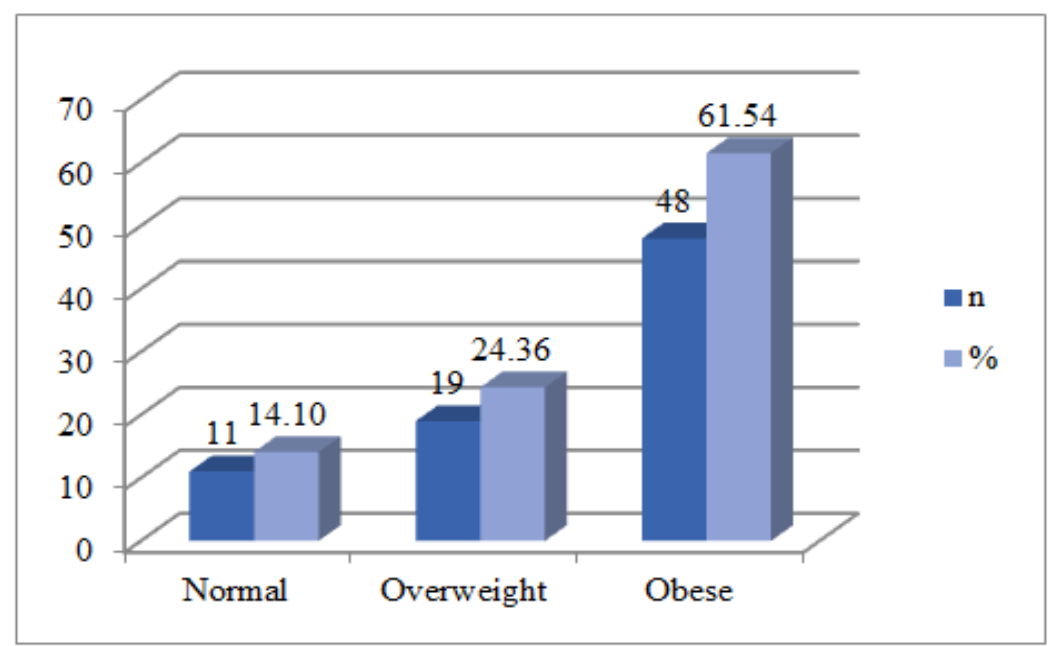

Fig-2: Distribute the study patients according to $\mathrm{BMI}(\mathrm{N}=78)$

Table-1: Comparison of serum 25(OH)D level in different groups of study people ( $\mathrm{N}=78)$

\begin{tabular}{|l|l|l|l|l|}
\hline Characteristics & \multicolumn{3}{|l|}{ Serum 25(OH)D level (ng/mL) } \\
\cline { 3 - 5 } \multicolumn{2}{|c|}{ N $(\%)$} & Mean \pm SD & P-value \\
\hline \multirow{3}{*}{ Family history of type 2 DM } & Present (\%) & $56(71.79 \%)$ & & \\
\cline { 2 - 4 } & Absent (\%) & $22(28.21 \%)$ & & \\
\hline \multirow{3}{*}{ Smoking status } & Non-smoker & $40(51.28 \%)$ & $26.86 \pm 4.31$ & \multirow{2}{*}{0.363} \\
& Smoker & $34(43.59 \%)$ & $27.10 \pm 2.49$ & \\
\cline { 2 - 4 } & Ex-smoker & $5(6.41 \%)$ & $42.62 \pm 1.71$ & \\
\hline & Normotensive & $38(6.41 \%)$ & $25.29 \pm 2.46$ & \multirow{2}{*}{0.277} \\
\cline { 2 - 4 } & Borderline hypertensive & $31(39.74 \%)$ & $32.57 \pm 5.32$ \\
\cline { 2 - 4 } & Hypertensive & $8(10.26 \%)$ & $20.84 \pm 3.66$ & \\
\hline
\end{tabular}

Table-2: Correlations with other variables divide in two groups $(n=78)$

\begin{tabular}{|c|c|c|c|c|}
\hline \multirow[t]{2}{*}{ Variables } & \multicolumn{2}{|c|}{ Male with Type-2 DM(n=58) } & \multicolumn{2}{|c|}{ Female with Type-2 DM $(n=20)$} \\
\hline & $\mathbf{r}$ & $\mathbf{p}$ & $\mathbf{r}$ & $\mathbf{p}$ \\
\hline BMI and $25(\mathrm{OH}) \mathrm{D}$ level & -0.391 & 0.017 & -0.08 & 0.794 \\
\hline SBP and $25(\mathrm{OH}) \mathrm{D}$ level & -0.059 & 0.728 & -0.229 & 0.451 \\
\hline DBP and 25(OH)D level & 0.146 & 0.388 & 0.23 & 0.45 \\
\hline FPG and $25(\mathrm{OH}) \mathrm{D}$ level & 0.334 & 0.044 & -0.537 & 0.058 \\
\hline
\end{tabular}


Table-3: Multiple regressions for serum 25(OH) D level in T2DM

\begin{tabular}{|l|l|l|l|l|l|}
\hline Variables & B & SE & Beta & t & p \\
\hline Sex & 13.114 & 8.719 & 0.318 & 1.504 & 0.14 \\
\hline BMI & -1.24 & 0.798 & -0.267 & -1.533 & 0.128 \\
\hline Systolic BP & -0.405 & 0.244 & -0.308 & -1.657 & 0.105 \\
\hline Diastolic BP & 0.958 & 0.653 & 0.293 & 1.468 & 0.15 \\
\hline Family H/O T2DM & 2.252 & 6.426 & 0.056 & 0.35 & 0.728 \\
\hline Smoking status & 4.329 & 6.66 & 0.145 & 0.65 & 0.519 \\
\hline FPG & -0.914 & 0.859 & -0.166 & -1.065 & 0.293 \\
\hline
\end{tabular}

Table-4: Distribution of the study people according to the vitamin D status

\begin{tabular}{|l|l|l|l|l|}
\hline \multirow{2}{*}{ Vitamin D deficiency } & \multicolumn{2}{|l|}{ Male } & \multicolumn{2}{l|}{ Female } \\
\cline { 2 - 5 } & $\mathrm{n}$ & $\%$ & $\mathrm{n}$ & $\%$ \\
\hline Normal & 24 & 41.38 & 8 & 40.00 \\
\hline Insufficient & 22 & 37.93 & 11 & 55.00 \\
\hline Deficient & 12 & 20.69 & 1 & 5.00 \\
\hline
\end{tabular}

\section{DISCUSSION}

The aim of the present study was to determine vitamin $\mathrm{D}$ status in Type-2 diabetes mellitus (DM) patients. Out of 78 patients we found 58(74.36\%) male and $20(25.64 \%)$ female. From the total sample size, the majority belonged to the obese category $48(61.54 \%)$, then 19(24.36\%) were overweight and 11(14.10\%) were of normal body weight. Looking at the clinical and laboratory characteristics of the patients, $56(71.82 \%)$ had a family history of type $2 \mathrm{DM}$ and $22(28.21 \%)$ patients was absent. Of the 78 patients, 40(51.28\%) were non-smoker, $5(6.41 \%)$ were ex-smoker, and the remaining 34(43.59\%) were smokers. Categorizing them based on their blood pressure, $8(10 \%)$ were hypertensive, 31(39.74\%) were borderline hypertensive, and the remaining $38(6.41 \%)$ were of normotensive category. The mean serum $25(\mathrm{OH}) \mathrm{D}$ concentration in our study was $27.91 \pm 2.58 \mathrm{ng} / \mathrm{mL}$ (mean $\pm \mathrm{SD})$, which is higher than the findings. $(18.81 \pm 15.18 \mathrm{ng} / \mathrm{ml}$, mean \pm SD) and $(7.34 \pm 1.19 \mathrm{ng} / \mathrm{mL}$ mean \pm SD) [26]. Our study observed no significant difference of $25(\mathrm{OH}) \mathrm{D}$ levels between males and females which is in agreement with the findings [27]. The correlation between $25(\mathrm{OH})$ D levels and other factors, divided between the male and female groups showed that significant inverse correlation with BMI only in male groups $(\mathrm{r}=-0.391, \mathrm{p}=0.017)$, also showed that $25(\mathrm{OH})$ $(\mathrm{r}=0.334, \mathrm{p}=0.044)$ FPG in males; but in females it had negative correlation $(\mathrm{r}=-0.537, \mathrm{p}=0.058)$ with the same. On the contrary, in an Indian study in the general population, women were found to have a higher prevalence of vitamin D deficiency compared with men [28]. Sex was found to not have any significant effect to be an important confounder of $25(\mathrm{OH}) \mathrm{D}$ level in our study. Our study found no significant difference of $25(\mathrm{OH}) \mathrm{D}$ levels between age groups $<40$ years and $\geq 40$ years. On the contrary, we found $25(\mathrm{OH}) \mathrm{D}$ levels to be increased with increasing age [29]. In this study there were no significant differences of $25(\mathrm{OH}) \mathrm{D}$ levels among normal weight, overweight and obese T2DM subjects; but 25(OH)D levels had a significant negative correlation with BMI only male subjects. The study had demonstrated an inverse relationship between $25(\mathrm{OH}) \mathrm{D}$ levels and BMI in subjects with metabolic syndrome or diabetes; those with high BMI had lower 25(OH)D levels [30]. No direct correlations between BMI and $25(\mathrm{OH}) \mathrm{D}$ level was noticed during the study [28]. Our study found a significant positive correlation of 25(OH)D level and FPG in males, but in females, D level had a negative correlation with FPG though it was non-significant. The study also found a significant negative correlation of D level with FPG [27]. None among the variables of age, sex, smoking status, BMI, systolic BP, diastolic BP, family history of $\mathrm{DM}$, and smoking status were found to influence $25(\mathrm{OH}) \mathrm{D}$ level independently \& $\mathrm{p}$ value is not significant for all. In Vitamin-D status was 24(41.38\%) found normal in male and $8(40.00 \%)$ in female; insufficient found $22(37.93 \%)$ in male and $11(55.00 \%)$ in female; deficient found $12(20.69 \%)$ in male and $1(5.00 \%)$ in female. Recent studies done in India found a higher prevalence $(81 \%)$ found that of Type-2 diabetes mellitus (DM) diabetes mellitus patients were Vit-D deficient or insufficient while around $67 \%$ of healthy control subjects were either deficient or insufficient as well [27]. In another study, D deficiency was found in $97.5 \%$ of the newly diagnosed Type-2 diabetes mellitus subject [28]. A large proportion of patients previously diagnosed as Type- 2 diabetes mellitus taking anti-diabetic drugs have also been found to have subnormal levels of vitamin D. Their study found that the frequency of D-deficient and Dinsufficient Type-2 diabetes mellitus (DM) diabetes mellitus patients were $71.4 \%$ and $15 \%$ respectively. This is higher than the frequency of Vit-D deficiency in the general population of India $(70 \%)$. A recent Saudi Arabian study also found a higher frequency of subnormal vitamin $\mathrm{D}$ in T2DM patients $(76.6 \%$ deficient and $22.2 \%$ insufficient) [31].

\section{Limitations of the study}

This was a single centered study with a small sized sample. The sample size was small and no healthy control group was taken, so the causal role of vitamin $\mathrm{D}$ levels on type $2 \mathrm{DM}$ could not be 
determined. Seasonal variation, the extent of sunlight exposure, and dietary vitamin $\mathrm{D}$ intake were also not quantified. So the findings of this study may not reflect the exact scenario of the whole country.

\section{CONCLUSION AND \\ RECOMMENDATIONS}

A large portion of Type-2 diabetes mellitus (DM) subjects in Bangladesh has subnormal vitamin $\mathrm{D}$ as revealed by our study. Vitamin D level had a significant negative correlation with BMI only male subjects and showed no correlation with sex and other veriables. However, wider scale studies are needed to properly understand the vitamin D status in Type-2 diabetes mellitus (DM) in our country. Vitamin D plays an important role in activating immune cells and enhancing their work in addition to regulating insulin secretion while reducing cell resistance to insulin.

\section{REFERENCES}

1. International Diabetes Federation. IDF Diabetes Atlas. $7^{\text {th }}$ edn. Brussels, Belgium: International Diabetes Federation. 2015.

2. Nazik S, Nazik H, Şahin AR, Selma AT. Evaluation of self-care agency of patients with diabetic foot infection: A cross-sectional descriptive study. Journal of Surgery and Medicine. 2019 Mar 15;3(3):214-7.

3. Pu D, Lei X, Leng W, Zheng Y, Chen L, Liang Z, Chen B, Wu Q. Lower limb arterial intervention or autologous platelet-rich gel treatment of diabetic lower extremity arterial disease patients with foot ulcers. Annals of translational medicine. 2019 Sep;7(18);485-485.

4. Zhang X, Ran X, Xu Z, Cheng Z, Shen F, Yu Y, Gao L, Chai S, Wang C, Liu J, Liu J. Epidemiological characteristics of lower extremity arterial disease in Chinese diabetes patients at high risk: a prospective, multicenter, cross-sectional study. Journal of Diabetes and its Complications. 2018 Feb 1;32(2):150-6.

5. Bus SA, Van Deursen RW, Armstrong DG, Lewis JE, Caravaggi CF, Cavanagh PR, International Working Group on the Diabetic Foot (IWGDF). Footwear and offloading interventions to prevent and heal foot ulcers and reduce plantar pressure in patients with diabetes: a systematic review. Diabetes/metabolism research and reviews. 2016 Jan;32:99-118.

6. Alavi A, Sibbald RG, Mayer D, Goodman L, Botros M, Armstrong DG, Woo K, Boeni T, Ayello EA, Kirsner RS. Diabetic foot ulcers: Part I. Pathophysiology and prevention. Journal of the American Academy of Dermatology. 2014 Jan 1;70(1):1-e18.

7. Boulton, AJ. The Pathway to Foot Ulceration in diabetes Med Clin N Am. 2013, 97, 775-790.

8. Prasad P, Kochhar A. Interplay of vitamin D and metabolic syndrome: a review. Diabetes \&
Metabolic Syndrome: Clinical Research \& Reviews. 2016 Apr 1;10(2):105-12.

9. Maurya VK, Bashir K, Aggarwal M. Vitamin D microencapsulation and fortification: Trends and technologies. The Journal of steroid biochemistry and molecular biology. 2020 Feb 1;196:105489.

10. Holick MF. Sunlight, vitamin D and health: A D-lightful story. Oslo: The Norwegian Academy of Science and Letters. Espen Bjertness. 2008.

11. Ozkan GO. The Effects of Vitamin D on Obesity, Insulin Resistance and Type 2 Diabetes. J Obes Overweig. 2019; 5(1):101.

12. Grimnes G, Emaus N, Joakimsen RM, Figenschau Y, Jenssen T, Njølstad I, Schirmer H, Jorde R. Baseline serum 25- hydroxyvitamin D concentrations in the Troms $\varnothing$ Study 1994-95 and risk of developing type 2 diabetes mellitus during 11 years of follow- up. Diabetic Medicine. 2010 Oct;27(10):1107-15.

13. Anderson JL, May HT, Horne BD, Bair TL, Hall NL, Carlquist JF, Lappé DL, Muhlestein JB, Group IH. Relation of vitamin D deficiency to cardiovascular risk factors, disease status, and incident events in a general healthcare population. The American journal of cardiology. 2010 Oct 1;106(7):963-8.

14. Mitri J, Muraru MD, Pittas AG. Vitamin D and type 2 diabetes: a systematic review. EJCN. 2011; 65:1005-15.

15. Green RT, Gambhir KK, Nunlee-Bland G, Odonkor WA, Ganta VA. Maintenance of longterm adequate levels of vitamin D lowers HbA1c in African American patients with type 2 diabetes. Ethn Dis. 2014; 24:335-41.

16. Anyanwu AC, Fasanmade OA, Odeniyi IA, Iwuala S, Coker HB, Ohwovoriole AE. Effect of Vitamin D supplementation on glycemic control in Type 2 diabetes subjects in Lagos, Nigeria. Indian J Endocr Metab. 2016; 20:189-94.

17. Holick MF. Vitamin D deficiency. N Engl J Med. 2007; 357:266-81.

18. Mitchell DM, Henao MP, Finkelstein JS, Burnett-Bowie SM. Prevalence and Predictors of Vitamin D Deficiency in Healthy Adults. Endocr Pract. 2012; 18:914-23.

19. Goswami R, Gupta N, Goswami D, Marwaha RK, Tandon N, Kochupillai N. Prevalence and significance of low 25- hydroxyvitamin D concentrations in healthy subjects in Delhi. Am J Clin Nutr. 2000; 72:472-5.

20. Harinarayan CV, Ramalakshmi T, Venkata PV. High prevalence of low dietary calcium and low vitamin D status in healthy south Indians. Asia Pac J Clin Nutr. 2000; 72:690-3.

21. Ritu G, Gupta A. Vitamin D deficiency in India: prevalence, causalities and interventions. Nutrients. 2014; 6:729-75.

22. Kumar A, Haria JM. Vitamin D status and type 2 diabetes mellitus in Indians: a case- control study. Int J of Scientific Study. 2014; 2:104-7. 
23. Palazhy S, Viswanathan V, Muruganathan A. Prevalence of 25-hydroxy vitamin D deficiency among type 2 diabetic subjects of South India. Int J Diabetes Dev Ctries. 2017; 37:69-73.

24. Dutta D, Maisnam I, Shrivastava A, Sinha A, Ghosh S, Mukhopadhyay P, Mukhopadhyay S, Chowdhury S. Serum vitamin-D predicts insulin resistance in individuals with prediabetes. The Indian journal of medical research. 2013 Dec;138(6):853-60.

25. Holick MF, Binkley NC, Bischoff-Ferrari HA, Gordon CM, Hanley DA, Heaney RP, Murad MH, Weaver CM. Evaluation, treatment, and prevention of vitamin D deficiency: an Endocrine Society clinical practice guideline. The Journal of Clinical Endocrinology \& Metabolism. $2011 \mathrm{Jul}$ 1;96(7):1911-30.

26. Misra A, Chowbey P, Makkar BM, Vikram NK, Wasir JS, Chadha D, Joshi SR, Sadikot S, Gupta R, Gulati S. Consensus statement for diagnosis of obesity, abdominal obesity and the metabolic syndrome for Asian Indians and recommendations for physical activity, medical and surgical management. Japi. 2009 Feb;57(2):163-70.
27. Laway BA, Kotwal SK, Shah ZA. Pattern of 25 hydroxy vitamin D status in North Indian people with newly detected type 2 diabetes: A prospective case control study. Indian J Endocr Metab. 2014; 18:726-30.

28. Daga RA, Laway BA, Shah ZA, Mir SA, Kotwal SK, Zargar AH. High prevalence of vitamin D deficiency among newly diagnosed youth-onset diabetes mellitus in north India. Arq Bras Endocrinol Metab. 2012; 56:423-8.

29. Harinarayan CV, Ramalakshmi T, Venkata PV. High prevalence of low dietary calcium and low vitamin D status in healthy south Indians. Asia Pac J Clin Nutr. 2000; 72:690-3.

30. Lagunova Z, Porojnicu AC, Lindberg F, Hexeberg S, Moan J. The dependency of vitamin $\mathrm{D}$ status on body mass index, gender, age and season. Anticancer Res. 2009; 29: 3713-20.

31. Alhumaidi M, Agha A, Dewish M. Vitamin D Deficiency in Patients with Type-2 Diabetes Mellitus in Southern Region of Saudi Arabia. Maedica. 2013; 8:231-6. 